\title{
Sheikh Wan Ahmad al-Fatani and the Malay Publications in the Middle East
}

\author{
Ermy Azziaty Rozali ${ }^{1}$ \\ ${ }^{1}$ Department of Arabic Studies and Islamic Civilisation, Faculty of Islamic Studies, The National University of \\ Malaysia, Malaysia \\ Correspondence: Ermy Azziaty Rozali, Department of Arabic Studies and Islamic Civilization, Faculty of \\ Islamic Studies, The National University of Malaysia, Malaysia. E-mail: ermy@ukm.edu.my
}

Received: April 5, 2015 Accepted: June 10, 2015 Online Published: August 18, 2015

doi:10.5539/ass.v11n24p90 URL: http://dx.doi.org/10.5539/ass.v11n24p90

\begin{abstract}
The Middle East had become the focus for the Malays to gain education. However, the expansion of publication in Malay script do plays substantial role in the development of intellectual and knowledge. Renowned scholar, Sheikh Wan Ahmad al-Fatani acts by printing various works of Islamic knowledge into Malay script. It is said that he gained the capital and support from the Ottoman Dawlah. Under the reign of Sultan Abdul Hamid II (1876-1909) he was appointed as the supervisor of Matbaah al-Mirriyyah al-Kainah in Mecca. Financing from the Ottoman Dawlah helps the Malay script works to be printed on a large scale and disseminated throughout the Muslim world. Therefore, this paper is designated to study of Sheikh Wan Ahmad and expansion of publication in Malay printings script in the Middle East that produce significant contributions in the Malay World epistemology image formation within the Middle East region.
\end{abstract}

Keywords: Sheikh Wan Ahmad al-Fatani, Middle East, Malay publication

\section{Introduction}

Based on the review of the early Malay publications, namely around 1850's, indicated the existence of places of publication and printing which crosses the archipelago. Malay books during that period contain copyrights of the publisher and printing from the Malay Archipelago, Europe, Middle East, South Africa, continent of India, Hong Kong and Turkey. The biggest operation conducted outside the Malay Peninsula and Singapore was in the Middle East and Turkey. The Malays has traveled to the Middle East as early as in fifteenth and sixteenth century to perform pilgrimage and studied Islam. The earliest school in Mecca was Masjid al-Haram. Group of students were lectured by renowned scholars such as Sheikh Muhammad Arshad al-Banjari and Sheikh Nawawi al-Bantani as soon as they finished their daily prayers. Aside from Mecca, Malay students were also travelled to Istanbul and other cities in the Middle East. The authors of Malay script end their long academic sojourn in the region. They lived and studied in Mecca, Medina, Ta'if, Cairo, Jerusalem, Beirut, Istanbul, and Alexandria under the scope of renowned scholars (Note 1).

Many had come back to the homeland, although there were some that choose to stay and works as writer, teacher and scribe. Some of them held important positions such as Mufti and religious leader. Some of the earliest writer that stayed in Mecca was Abdul Malik bin Abdullah, Muhammad Arshad al-Banjari, Nawawi al-Bantani and Daud al-Fatani. They were famous Malay manuscript writers. When printing equipment were introduced in Istanbul, Cairo and Mecca, their works was published in the form of printed copies. (Note 2)

\section{The Publishing of and Printing Malay Script in the Middle East}

When discussing about the printings of Malay books, we can't exclude the roles of the publication center that is located in the Middle East. The relation between the Malay Archipelago and the said region was not based on the education field and prestigious scholars only, but also related to the publishing and printing aspects. The mass printings in the Middle East also lead to the increasing of distribution of Malay books to other Islamic region, including Malay Archipelago.

In 1729, a Hungarian named Ibrahim Muteferika who converted to Islam, opened the first publishing spot in Istanbul, which was also the earliest in Turkey for Arabian printings. Early printings in Turkish and Arabic language were not allowed by the current ruler during that time. Before that, Jewish refugees from Spain had 
used the printing equipments from the Middle East in 1493 or 1494 . However, their printing activities were limited to Ibrani and other European languages. Sons of Turkey Ambassador in Paris, Ibrahim and Said Helebi were responsible in managing the first Turkey printing center. Unfortunately, the printing center could only lasts for thirteen years and was producing works which was not religious. The printing center was reopened by Sultan Abdul Hamid I in 1784 and it expanded vastly. During that time, Syria got its own printing center. These are the place where the works by Muslims in Mecca, especially works in Arabic language first printed. (Note 3)

The earliest printing in Egypt was developed in Bulaq in 1822. It was based on the wish made by the ruler, Muhammad Ali. The printings in Egypt played huge role in spreading and developing Islamic ideas. There was no hindrance while doing so in Egypt. The printings promote the opinion regarding the revival and improved Islam as well as the ideas of uniting the Muslims. Numbers of books, newspapers and magazines were printed and published in Arabic, English, Turkish and other Eastern language. (Note 4)

The printing and publishing activities in the Middle East entered a new phase in 1884 when Sheikh Wan Ahmad bin Muhammad Zain al-Fatani was appointed as supervisor and interpreter for a new printing called Matbaah al-Miriyyah al-Kainnah in Mecca by the Dawlah Ottoman. (Md. Sidin \& Mohammad Redzuan $2000: 60$ ). Based on the number of books printed since 1884 in Mecca, shows the importance of Malay people in Mecca especially when it comes to the trust gained from Dawlah Ottoman. (Note 5)

The Malay readers in the Middle East were students, teachers and the pilgrims. The opening of Suez Canal in 1869 increased the communication link. Based on the report during the mid $20^{\text {th }}$ century, about 2000 pilgrims went for Mecca and it was increased to 7000 pilgrims at the end of the century. Aside from Malay readers in Mecca, Cairo and other parts in the Middle East, there were also regular buyers from Malay Peninsula, Indonesia, Patani and Cambodia. The importation of books were made by pilgrims head and Arabian traders. (Note 6)

One of the active publisher and distributor of Malay books was Ahmad bin Abdullah Mujallid or Ahmad Mujallid who was of Indian descent. In 1892, he listed out almost 50 titles of books written by a few writers which he published them himself. His activities were operated at Bab al-Salam, near to Masjid al-Haram. Most of the books published by him were printed at Matbaah al-Karimiah and some of the books were already printed by Sheikh Wan Ahmad al-Fatani at Matbaah Fataniah. (Note 7)

The discussion on Malay printings in the Middle East won't be complete if Sheikh Wan Ahmad Muhammad Zain al-Fatani were to left behind. He had a close relationship to Sheikh Mustafa al-Babi al-Halabi. Sheikh Wan Ahmad was appointed as a proofreader and interpreter for the books that were processed at Matbaah Mustafa al-Babi al-Halabi. At that time, he proposed to print the books written by the parson from Malay world. Unfortunately, Sheikh Mustafa opposed Sheikh Wan Ahmad's idea due to the problems of marketing the piece. His reason was also supported with the fact of lesser Malay people in Egypt as well as other parts of the Middle East.

In addition, Sharif of Mecca does not allowed books written in other languages except in Arabian to enter Medina and Mecca. Due to the disappointment of his idea being turned down, Sheikh Wan Ahmad then befriended al-Amjad al-Kasymiri Fida Muhammad and the latter's son, Abdul Ghani agreed to sponsor the printings of Hidayah al-Salikin written by Syeikh Abdul Samad al-Falembani. The book was printed by Sheikh Hassan al-Tukhi printing near to Masjid Jami' al-Azhar in Egypt and it was the first Malay book printed in Egypt (Note 8). To broaden the publishing of Malay books, Sheikh Wan Ahmad approached the owner of matbaah or printing house in Egypt in order to make sure that the religious manuscript written in Arabic or Malay language to be read and flourish.

The Malay language that were used in the writings of Malay books was usually used as Arabian language in Lisan al-Jawi and is the spoken language for the people in Malay Peninsula, Patani and other parts in the region. The writings of Malay books were meant for those who were not skillful in Arabic. These books were not only used by the Malay people who were living within the community from the Malay world, but also used by any people who lived either temporarily or permanently in Mecca. The Malay people who lived in Mecca usually pursuit the knowledge from parson who were from Patani and Dutch East India. (Note 9)

Sheikh Wan Ahmad al-Fatani was of Islamic religious broadcasters' descent which originated from Hadhramaut and his real name is Syeikh Wan Ahmad bin Muhammad Zainal Abidin bin Mustafa bin Muhammad al-Fatani. Born in 1956 in Kampung Jambu, Patani, Thailand and died in 1908. He was buried in al-Ma'la's burial ground which is near to Siti Khadijah's tomb. He was the first Malay parson to become an interpreter of Malay books. The first book printed by him was Hidayah al-Salikin, written by Sheikh Abdul Samad al-Falimbani with the first printing in $1300 \mathrm{H}$. Before this period, the Malay books were in handwritten. (Note 10) 
He received his early education from his own family, which comprises parson including his father and his uncle, Syeikh Abdul Qadir (Tok Bendang Daya) and later furthered his studies in Mecca and pursuit the knowledge from other parson. One of the parsons was Syeikh Abdul Rahim al-Kabuli. Later on, he furthers his studies at Bait al-Maqdis and Masjid Jami' al Azhar. He was the first Malay to study at the said institution. (Note 11) One of his piece that mentioned Dawlah Ottoman was Hadiqatul Azhar wa al-Rayahin and Tarikh Turki Utsmani. (Note 12)

\section{Sheikh Wan Ahmad's Focuses and Accuracy in Printing Malay Books}

With the encouragement and support from Dawlah Ottoman, the Islamic books including Malay books were printed massively and distributed throughout the Islamic world. Sheikh Wan Ahmad constantly traveled back and forth between Egypt, Mecca and Istanbul due to printing busines. (Note 13) One of Malay parson named Sheikh Utsman Syihabuddin al-Funtiani composed a poem and dedicated it to Sultan Abdul Hamid II for his effort :-

Making a mark in the exceptionally good books

Therefore many books translated to Malay

As he loves to translate

Dedicated for its benefit

One book turned to thousands of copies

His rewards and deeds prolonged

The poem consists of 10 verse and the first verse praising Sultan Abdul Hamid II and it was mentioned in Kitab Fath al-Makkah, Matba'ah al-Mirriyah al-Kainah print in Mecca 1311H/1898M. (Note 14) Sheikh Utsman bin Shihabuddin al-Banjari was a son of famous parson, originated from Pontianak, Kalimantan, Indonesia. He received his early education from his family before continued his studies in Mecca. Some of his teachers were Sayid Muhammad Shalih bin Abdul Rahman al-Zawawi, Syeikh Abdul Hamid al-Syarwani and Syeikh Abdul Qadir bin Abdur Rahman al-Fatani. Some of his written works were Tajul Arus, Fathul Makkah, Tanwirul Qulub fi Isqati Tadbir al- 'Uyub, Risalah Tafsir Surah Yasin dan lain-lain. (Note 15)

Thanks to the role played by Sheikh Wan Ahmad, the printing center in Mecca produced a huge number of Malay books. This realized his dreams of expanding Islamic knowledge through Malay language. He made careful planning to print and publish the books of high quality. He edited the famous manuscripts written by Nuruddin al-Raniri, Abdul Samad al-Falembani, Abdul Malik Abdullah, Muhammad Nafis al-Banjari, Muhammad Arshad al-Banjari, Muhammad b. Ismail Daud al-Fatani and Muhammad Zain bin Jalaludin and specifically Daud al-Fatani. (Note 16)

Some of the famous works by Sheikh Daud al-Fatani that was printed in Mecca was Furu' al-Masail that had been used in Indonesia, Kasyf al-Ghummah, and Jam'al al-Fawaid. With the printing houses were sponsored by the Dawlah Ottoman, it was obvious for Malay books to be printed as it gained important place. (Note 17) Sheikh Wan Ahmad had also been entrusted to edit the Arabic books written by figures like Abu Bakar al-Shata, Jaa'far Ismail al-Barzanji, Abdullah bin Uthman al-Makki and Sulaiman al-Jazuli. Although he was busy editing and interpreting books, he managed to write his own books. Starting from 1884, he wrote more than 30 books in Arabic and 20 books in Malay. This success gained by Sheikh Wan Ahmad inspiring Malay students and teachers to publish their own writings in the Middle East. (Note 18)

Sheikh Wan Ahmad passed away in Mina, Saudi Arabia in 1908. It was not clear of whom replacing him as a supervisor in Malay publication and printing. However, Maktabah Fataniah and Ahmad bin Abdullah continued to become an important distributor for Malay books in Mecca until the early $20^{\text {th }}$ century. During these times, Malay books were started to be printed by other printing houses, including Matbaah al-Turki al-Majidiah. The activities of Malay printings in Mecca was followed by the effort made in Egypt and Turkey. Eventhough there were printing activities in Malay conducted in Istanbul and Egypt before that, the printing center in Mecca had driven them to print bigger number of books. The increasing number of Malay students in Cairo motivates them. In early 1920s there were few publishers and printings which acted as a producer and distributor of the Malay books. One of the successful publisher was Mustafa al-Babi al-Halabi and Dar Ihya al-Kutub al-Arabiyyah. (Note 19)

There were numbers of printing houses which was owned by the Malay. Matbaah al-Marbawiah was one of them as it was pioneered in 1920 s by Muhammad Idris al-Marbawi which was a famous Malay parson that resides in Egypt. Furthermore, there was also Matbaah al-Ittihadiyyah, which was built by Muhammad Fadlullah Suhaimi al-Azhari in 1914. Both Muhammad Idris al-Marbawi and Muhammad Fadlullah Suhaimi were Malay 
eminent writer based in the Middle East during that time. They were involved in the effort of editing publication made by the Malay students in Cairo. Between 1925-1940 there were at least four Malay magazine, three of them were Seruan Azhar (1925-1928), Pilehan Timur (1927-1927) and Kitab Perbendaharaan Ilmu (1929-?) published in Cairo while Perseruan Islam (1937-?) was published in Mecca. Other writer that lives in the same era with them was Ahmad bin Abdul Latiff, preacher of Shafi'i sect in Mecca. He wrote four books within 1912 to 1927. Hussain Nasir bin Muhammad Taib al-Mas'udi al-Banjari published two books in Cairo. (Note 20)

To publish or to print the work, Sheikh Wan Ahmad first collected various versions of that particular work. If he failed to retrieve the original copy, he would collect more duplicate copies of it. Apart from using the original copy and its duplicators, he also referred to litographed copies that was published. If the Malay work is a translated work of Persian and Arabic, he will make comparisons between the translated work and the original work by the author. If the work is made by an unknown author, Sheikh Wan Ahmad will use linguistic knowledge to determine the style of the language that was used by the author or the style of the language used in a district. (Note 21)

When it comes to translating a piece of work, Sheikh Wan Ahmad will make comparisons to the original piece, other than using the translated copies. This is to correcting the language errors as well as the confusion that can be found in the translated copies. This measure was taken when he interpreted Kasyf al-Ghummah by Sheikh Daud bin Abdullah al-Fatani.

The comparisons of the style of language were made in order to determine the originality of a piece of work. It was applied to determine the authenticity of Syarah Hikam Melayu. At first, it was said to be a work of a person from Terengganu but, after an inspection, it was actually made by a person from Acheh. Sheikh Wan Ahmad cancelled the first findings when he retrieved a new one and it was mentioned in the 1884 print of Syarah Hikam Melayu by Matbaah al-Miriyyah al-Kainnah, Mecca. (Note 22)

In order to determine the quality of the publishing and printing of Malay books, Sheikh Wan Ahmad does not hesitate to criticize and protest if he found inaccurate facts and invalidity. He did this when the books printed by Ahmad Mujallid in Bab al-Salam were credited to Sheikh Daud al-Fatani as the author since he was a famous parson in order to attract buyers. Sheikh Wan Ahmad did a research and managed to determine that the small pamphlet on twenty traits was not written by Sheikh Daud al-Fatani. His expertise were not limited to knowing the language style used by Sheikh Daud al-Fatani, but also the language style used by other authors which he had worked on before. Therefore, he opposed this attitude that was motivated by profit. (Note 23)

\section{Conclusion}

Thoroughly we can see that Malay books that were spreading within the Malay people were also been printed outside of the Malay World. The Middle East and Turkey became the important center of publishing for Malay books. The expanding of the printing industry leads to the effort of increasing the printed works of famous Malay parsons. The dedicated figures were responsible in interpreting and printing Malay books, thus played an important role in enriching the treasured Malay's knowledge.

\section{References}

Abdullah, W. M. S. (1972). Al-Sheikh Wan Ahmad bin Muhammad Zain bin Mustapha bin Muhammad al-Patani. Dian. (Kota Bharu : Syarikat Dian Sdn. Bhd.

Abdullah, W. M. S. (2005). Syeikh Ahmad al-Fatani A Great Malay Muslim Scholar. Kuala Lumpur: Persatuan Pengkajian Khazanah Klasik Nusantara dan Khazanah Fathaniyah. Jil. 1.

al-Fatani, S. W. A. M. Z. (1990). Jurisdiction on Amphibious Animal. Wan Mohd Shaghir Abdullah (sunt.). Shah Alam: Penerbitan Hizbi.

http://ulama-nusantara-baru-blogspot-com/2006/11/sheikh-utsman-syihabuddin-ulama-html

Hurgronje, S. (1970). Mekka in the Latter Part of the Nineteenth Century. Terj. J. H. Monahan. Leiden: E. J. Brill.

Ishak, Md. S. A. (1998). Publication \& Printing Malay Book in 1807-1960. Kuala Lumpur: Dewan Bahasa Pustaka.

Ishak, Md. S., \& Othman, M. R. (2000). The Malays in the Middle East With Bibilography of Malay Printed Works Published in the Middlle East. Kuala Lumpur: University of Malaya Press.

Madmarn, H. (2001). The Pondok and Madrasah in Patani. Bangi: Penerbit UKM.

Malik, M. Z. A. (1994). Patani in Malay Civilization. Kuala Lumpur: Dewan Bahasa dan Pustaka. 


\section{Notes}

Note 1. Md Sidin Ahmad Ishak, 1998, Publication and Printing Malay Book 1807-1960, Kuala Lumpur, Dewan Bahasa Pustaka, pp. 105-106

Note 2. Ibid, pp. 107.

Note 3. Ibid.

Note 4. Ibid, pp.109.

Note 5. Hurgronje S. 1970, Mekka in the Latter Part of the Nineteenth Century. Translated. J.H Monahan, Leiden, E.J Brill, pp. 286.

Note 6. Md. Sidin \& Mohammad Redzuan, 2000 The Malays in the Middle East With Bibilography of Malay Printed Works Published in the Middlle East, Kuala Lumpur, University of Malaya Press, pp. 62.

Note 7. Ibid, pp. 63.

Note 8. Wan Mohd Shaghir Wan Abdullah, 2005 Syeikh Ahmad al-Fatani A Great Malay Muslim Scholar, Kuala Lumpur, Persatuan Pengkajian Khazanah Klasik Nusantara dan Khazanah Fathaniyah, pp. 96-99.

Note 9. Hasan Madmarn, 2001, The Pondok and Madrasah in Patani, Bangi : Penerbit UKM. 2001, pp. 121.

Note 10. Wan Mohd Shaghir Abdullah, 1972, "Al-Sheikh Wan Ahmad bin Muhammad Zain bin Mustapha bin Muhammad al-Patani”. Dian, Kota Bharu, Syarikat Dian Sdn. Bhd, pp. 43-45.

Note 11. Mohd Zamberi A. Malik, 1994, Patani In Malay Civilization, Kuala Lumpur : Dewan Bahasa dan Pustaka, 1994, pp.114.

Note 12. Wan Mohd Shaghir Abdullah, 2005, Syeikh Ahmad al-Fatani A Great Malay Muslim Scholar, Kuala Lumpur, Persatuan Pengkajian Khazanah Klasik Nusantara dan Khazanah Fathaniyah, pp. 13.

Note 13. Ibid, pp. 96-99.

Note 14. Ibid. p. 99.

Note 15. http://ulama-nusantara-baru-blogspot-com/2006/11/sheikh-utsman-syihabuddin-ulama-html.

Note 16. Md. Sidin \& Mohammad Redzuan, 2000 The Malays in the Middle East With Bibilography of Malay Printed Works Published in the Middlle East, Kuala Lumpur, University of Malaya Press, p. 60

Note 17. Hurgronje, S. 1970, Mekka in the Latter Part of the Nineteenth Century. Translated. J.H Monahan, Leiden, E.J Brill, pp 287.

Note 18. Wan Mohd Shaghir Abdullah, 2005, Syeikh Ahmad al-Fatani A Great Malay Muslim Scholar, Kuala Lumpur, Persatuan Pengkajian Khazanah Klasik Nusantara dan Khazanah Fathaniyah, p. 61

Note 19. Md Sidin Ahmad Ishak 1998, Publication and Printing Malay Book 1807-1960, Kuala Lumpur, Dewan Bahasa Pustaka, pp. 115.

Note 20. Ibid.

Note 21. Wan Mohd Shaghir Abdullah, 2005, Syeikh Ahmad al-Fatani A Great Malay Muslim Scholar, Kuala Lumpur, Persatuan Pengkajian Khazanah Klasik Nusantara dan Khazanah Fathaniyah, p. 92.

Note 22. Ibid, pp. 93-94.

Note 23. Ibid, p. 95.

\section{Copyrights}

Copyright for this article is retained by the author(s), with first publication rights granted to the journal.

This is an open-access article distributed under the terms and conditions of the Creative Commons Attribution license (http://creativecommons.org/licenses/by/3.0/). 